\title{
Urgency of Mathematics Learning in Preparing Cognitive Competence of Santri (Case Study at Misykatul Atsar Islamic Boarding School in Salatiga)
}

\author{
*Chayatun Ni'mah ${ }^{1}$ \\ MA Ma'ahid Kudus, Indonesia ${ }^{1}$ \\ Email: ch4yatunnikmah@gmail.com \\ *Corresponding Author \\ DOI: https://doi.org/10.18326/hipotenusa.v2i1.12-20
}

Submission Track:

Received : 06-06-2020

Final Revision : 28-06-2020

Available onlie : 17-06-2020

\begin{abstract}
Abstrak
Tujuan penelitian ini adalah untuk mengetahui Urgensi Pembelajaran Matematika dalam Menyiapkan Kompetensi Kognitif Santri Pondok Pesantren. Penelitian ini menggunakan pendekatan lapangan (field research) dengan metode kualitatif deskriptif. Subyek penelitian adalah pengurus, pengasuh, ustadzah matematika, serta para santri di pondok pesantren Misykatul Atsar. Dengan teknik observasi, wawancara, dan dokumentasi. Adapun hasil penelitian menunjukan bahwa: (1) urgensi pembelajaran matematika pondok pesantren Misykatul Atsar mengatakan penting dengan alasan: pertama, matematika sebagai bahasa untuk memahami ilmu pengetahuan. Kedua, matematika digunakan untuk memecahkan masalah. Ketiga, matematika sebagai implementasi ke pelajaran agama yang ada di pondok. Keempat, matematika sebagai bekal ketika Santri sudah keluar dari pondok. (2) Cara menyiapkan kompetensi kognitif Santri pondok pesantren Misykatul Atsar. Pertama, Cara Guru: memberi prolog dalam menyampaikan materi pembelajaran menggunakan bahasa yang mudah dipahami santri. Saat proses pembelajaran dengan menerangkan di depan kelas terkait materi yang sedang disampaikan dan memberi contoh soal kemudian diskusi tentang materi yang sudah disampaikan tadi dengan tanya jawab, setelah jelas diberi soal latihan. Kedua, Cara pengasuh dan pengurus: mendatangkan guru matematika ke pondok untuk mengajar matematika setiap seminggu sekali dan sering memberinya latihan. Kemudian meminta santri untuk mengulang materi dengan teman, mengerjakan contoh-contoh soal, membiasakan diri untuk menghitung, dan harus minat ketika belajar matematika.
\end{abstract}

Kata Kunci: Pembelajaran Matematika, Kompetensi Kognitif, Pondok Pesantren.

\begin{abstract}
The purpose of this study was to determine the urgency of learning mathematics in preparing the cognitive competencies of students of the Islamic Boarding School. This research uses a field approach with descriptive qualitative methods. The research subjects were administrators, caregivers, mathematical teachers, as well as students in the Misykatul Atsar Islamic boarding school. With observation, interview, and documentation techniques. The results of the study show that: (1) the urgency of mathematics learning at the Islamic boarding school Misykatul Atsar said it was important for the following reasons: first, mathematics as a language for understanding science. Second, mathematics is used to solve problems. Third, mathematics is implemented as a religious lesson in the cottage. Fourth, mathematics is the provision when Santri has left the hut. (2) How to prepare the cognitive competencies of the Santri Misykatul Atsar boarding school. First, the Teacher's Way: giving a prolog in delivering learning material using language that is easily understood by students.
\end{abstract}


During the learning process by explaining in front of the class the material being presented and giving examples of questions then the discussion about the material that was submitted earlier with questions and answers after clearly given the practice questions. Second, how to caregivers and administrators: bring math teachers to the cottage to teach mathematics once a week and often give him practice. Then ask students to repeat the material with friends, work on sample problems, get used to counting, and be interested when learning mathematics.

Keyword: mathematics learning, cognitive competence, islamic boarding school

\section{PENDAHULUAN}

Era modern saat ini sudah banyak berkembang pondok pesantren, baik itu pondok pesantren bernuansa tradisional, modern, dan campuran. Pondok pesantren tradisional, yaitu pondok pesantren yang mana pembelajarannya masih menggunakan pendekatan tradisional; selanjutnya pondok pesantren modern yaitu pondok pesantren yang menyelenggarakan kegiatan pembelajaran dengan modern melalui satuan pendidikan formal; kemudian pondok pesantren campuran yaitu pesantren yang kegiatan pendidikanya sesuai pondok pesantren tradisional dan pondok pesantren modern. Tak jarang dalam membawakan pembelajaranya berbeda-beda.

Pembelajaran dapat dipandang dari dıa sisi, pertama pembelajaran dipandang se ...... suatu sistem, yaitu pembelajaran terdiri dari sejumlah komponen yang terorganisir antara lain: materi pembelajaran, tujuan pembelajaran, strategi dan metode pembelajaran, media pembelajaran, evaluasi pembelajaran dan tindak lanjut pembelajaran (remidial dan pengayaan). Kedua, pembelajaran dipandang sebagai suatu proses, yaitu pembelajaran merupakan rangkaian upaya atau kegiatan pendidik (persiapan, pelaksanaan, menindaklanjuti) dalam rangka membuat peserta didik belajar (Komalasari Kokom, 2011: 3).

Lantas salah satu materi pelajaran yang seringkali menjadi momok dan permasalahan peserta didik adalah pelajaran matematika. Matematika adalah satu bidang studi hidup, yang perlu dipelajari karena hakikat matematika adalah pemahaman terhadap pola perubahan yang terjadi didalam dunia nyata dan di dalam pikiran manusia serta keterkaitan diantara polapola tersebut secara holistik. (Martini Jumaris, 2014: 177).

Tidak dipungkiri lagi bahwa di masyarakat beredar ungkapan "matematika itu menyeramkan" ini yang membuat peserta didik menjadi apatis, takut pada matematika, apalagi kemauan untuk mengerjakan soal-soal matematika. Namun ketika menilik pada urgensi suatu ilmu, matematika menjadi salah satu ilmu penting yang harus dipelajari, dipahami dan dikusai oleh semua lapisan masyarakat tak terkecuali santri sebagai generasi penerus, karena Al-Qur'an sudah menyatakan bahwa segala sesuatu diciptakan secara matematis dengan ukuran, perhitungan, rumus, atau persamaan tertentu yang sangat rapi dan teliti. Sehingga dalam Al-Qur'an sudah membenarkan akan adanya penerapan matematika. Berikut Firman Allah:

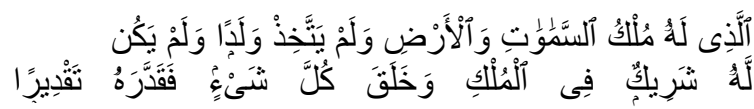

'Yang memiliki kerajaan langit dan bumi, tidak ada sekutu bagi-Nya dalam kekuasaan-Nya, dan Dia telah menciptakan segala sesuatu, dan Dia menetapkan ukuranukuranya dengan tepat.”, (QS. Al-Furqan: 2)

Bagi seorang peserta didik keberhasilan mempelajari matematika akan membuka pintu karir yang cemerlang. Bagi para warganegara, matematika akan menunjang pengambilan keputusan yang tepat. Bagi suatu negara, matematika akan menyiapkan warganya untuk bersaing dan berkompetisi di bidang ekonomi dan teknologi.

Kurniati Annisah (Jurnal of Mathematics Education,1, 2015: 4-5) matematika berguna untuk membentuk pribadi yang berkualitas dengan yaitu: (1) Sikap jujur, cermat, dan sederhana. (2) Sikap konsisten dan sistematis terhadap aturan. (3) sikap Adil. (4) sikap Tanggungjawab. Hal ini sejalan dengan pondok pesantren yang salah satu tujuanya adalah untuk membenruk pribadi yang berkualitas. 
Menurut Wijaya Ariyadi (2012: 7) tujuan pembelajaran matematika yang ditinjau dari posisi matematika dalam lingkungan sosial, yaitu; (1) Tujuan praktis, berkaitan dengan pengembangan kemampuan siswa untuk menggunakan matematika untuk menyelesaikan masalah yang terkait dengan kehidupan seharihari. (2) Tujuan kemasyarakatan, berorientasi pada kemampuan siswa untuk berpartisipasi secara aktif dan cerdas dalam hubungan kemasyarakatan. (3) Tujuan professional, pendidikan matematika harus bisa mempersiapkan siswa untuk terjun ke dunia kerja. Tujuan pendidikan ini memang dipengaruhi oleh pandangan masyarakat secara umum yang sering menepatkan pendidikansebagai alat untuk mencari pekerjaan. (4) Tujuan budaya, pendidikan merupakan suatu bentuk dan sekaligus produk budaya. Oleh karena itu, pendidikan matematika perlu menempatkan matematika sebagai hasil kebudayaan manusia dan sekaligus sebagai suatu proses untuk mengembangkan suatu kebudayaan. Menurut kurikulum

2013

(Kemendikbud, 2013) tujuan pembelajaran matematika adalah menekankan pada dimensi pedagogik modern dalam pembelajaran, yaitu menggunakan pendekatan Scientific (ilmiah). Dalam pembelajaran matematika kegiatan yang dilakukan agar pembelajaran bermakna yaitu mengamati, menanya, mencoba, menalar, menyaji, dan mencipta. Oleh karena itu, kebanyakan pendidik matematika lebih banyak melatih peserta didiknya untuk mengerjakan beberapa latihan soal daripada sekedar menjelaskan rumus dan menyuruh peserta didiknya untuk menghafal. Secara otomatis waktu yang dibutuhkan untuk latihan soal tidaklah sedikit. Ketika hal itu diterapkan kepada Santri yang mana mereka tinggal di wilayah pondok pesantren dengan berbagai aktivitas, maka dirasa hal tersebut kurang efisien.

Lalu untuk bisa mencapai pembelajaran matematika yang hasilnya dapat memuaskan, terdapat beberapa kompetensi harus dipenuhi. Menurut Sumiati dan Asra (2009:241) kompetensi berarti kemampuan. Kemampuan tersebut bisa terpenuhi dengan baik pastilah ada aspek-aspek yang mendukung suksesnya proses pembelajaran. Menurut Benyamin S. Bloom dalam Sumiati dan Asra (2009:245) Kompetensi terdiri atas 3 aspek, yaitu kompetensi kognitif (kecerdasan), kompetensi afektif (perasaan/sikap), dan kompetensi psikomotorik (keterampilan).

Guna menyiapkan santri untuk bisa eksis dalam dunia pendidikan umum dan tidak kalah hebat dengan peserta didik lain yang tidak tinggal di pondok, maka hal yang perlu dipahami betul adalah meningkatkan kompotensi kognitif santri. Kompetensi ini menurut Hall dan Jones dalam Sumiati dan Asra (2009:246) meliputi pengetahuan, pemahaman, dan perhatian. Sehingga perlulah santri menguasai hal ini.

Pada tanggal 14 Desember 2019, Peneliti melakukan observasi awal di lokasi Pondok Pesantren Misykatul Atsar. Dihasilkan bahwa Santri diberikan pembelajaran matematika setiap seminggu sekali dalam waktu 1,5 - 2 jam pembelajaran. Kemudian santri diberi materi mata pelajaran matematika sesuai UN (Ujian Nasional). Ketika santri dirasa sudah kompeten menguasai materi UN (Ujian Nasional), maka santri didaftarkan kejar paket untuk bisa mendapatkan ijazah. Hal ini menjadi permasalahan tersendiri bagi peneliti, yang mana waktu tersebut dirasa kurang cukup untuk memenuhi kebutuhan pembelajaran matematika dengan materi UN (Ujian Nasional) cukup banyak. Kompetensi kognitif yang akan didapatkan santri pun sangat kurang dan banyak Santri yang merasa tidak minat belajar matematika. Harusnya ketika pembelajaran ini dirasa cukup penting maka waktu yang diberikan tidak sesingkat itu.

Berdasarkan uraian permasalahan di atas, Peneliti tertarik untuk mengkaji lebih dalam mengenai urgensi pembelajaran matematika dalam menyiapkan kompetensi kognitif santri agar bisa sukses menghadapi kejar paket yang diselenggarakan oleh pondok pesantren tersebut. Sehingga peneliti melakukan penelitia yang berjudul "urgensi pembelajaran matematika dalam menyiapkan kompetensi kognitif santri pondok pesantren (studi kasus pondok pesantren misykatul atsar di salatiga tahun 2020)".

Bagaimana urgensi pembelajaran matematika di pondok pesantren Misykatul Atsar? Dan bagaimana cara menyiapkan kompetensi kognitif dalam pembelajaran matematika pada santri pondok pesantren Misykatul Atsar? merupakan fokus dalam penelitian ini. Tujuan penelitian ini adalah untuk mengetahui Urgensi Pembelajaran 
Matematika dalam Menyiapkan Kompetensi Kognitif Santri Pondok Pesantren (Studi Kasus Pondok Pesantren Misykatul Atsar di Salatiga Tahun 2020).

\section{METODE}

Penelitian ini merupakan kualitatif deskriptif dengan jenis penelitian lapangan (field research) bermaksud menggambarkan secara sistematis fakta dan karakteristik objek atau subjek yang diteliti secara tepat oleh peneliti. Penelitian lapangan (field research) yaitu penelitian yang pengumpulan datanya dilakukan di lapangan. Lapangan dalam hal ini diartikan sebagai lokasi penelitian, yaitu di Pondok Pesantren Misykatul Atsar Salatiga. Penelitian lapangan (field research) dapat juga dianggap sebagai pendekatan luas dalam penelitian kualitatif atau sebagai metode untuk mengumpulkan data kualitatif. Ide pentingnya adalah bahwa peneliti berangkat ke 'lapangan' untuk mengadakan pengamatan tentang suatu fenomena dalam suatu keadaan alamiah atau 'in situ' (Moleong, 2011: 26).

Penelitian dilakukan di Pondok Misykatul Atsar Kradenan Rt 02 Rw 06, Kel. Tingkir Lor, Kec. Tingkir, Kota Salatiga. Subjek penelitian ini adalah para pelaksana, para pendukung, dan para sasaran. Para pelaksana yang dimaksud adalah guru matematika, sedangkan untuk para pendukung adalah pengasuh atau pengurus pondok pesantren. Kemudian untuk para sasaran adalah para santri. Dari setiap subjek penelitian diambil 2 orang sehingga banyaknya subjek penelitian ada 6 orang. Pemilihan ini diambil agar mendapatkan informasi yang valid sesuai yang peneliti harapkan.

Pada penlitian ini, Peneliti menggunakan beberapa teknik pengumpulan data, yaitu observasi, wawancara, dan dokumentasi. Menurut pendapat Bungin dalam Ibrahim (2015: 81). Observasi atau pengamatan adalah kegiatan keseharian manusia dengan menggunakan panca indra mata sebagai alat bantu utamanya. Dalam proses ini peneliti melakukan observasi secara langsung dengan jenis observasi non partisipan untuk mendapatkan gambaran yang utuh terkait fokus penelitian, yaitu lebih menekankan pada saat proses pembelajaran matematika santri, aktivitas santri, pengasuh, serta ustadzah pondok pesantren Misykatul Atsar.
Wawancara. Wawancara dilakukan untuk mengetahui hal-hal secara mendalam yang tidak diperoleh melalui teknik observasi. Peneliti menggunakan model wawancara terbuka dan terstruktur dengan dilakukan secara online. Hal ini digunakan sebagai metode pengumpulan data terkait pembelajaran matematika dalam menyiapkan kompetensi kognitif santri dan bagaimana tanggapan masing-masing informan yakni kepada Pengurus, Pengasuh, Ustadzah dan Santri pondok pesantren Misykatul Atsar.

Dokumentasi. Menurut Sugiyono (dalam Ibrahim, 2015: 94) dokumen adalah catatan-catatan peristiwa yang telah lalu, yang bisa berbentuk tulisan, gambar atau karya monumental seseorang.Pada penelitian ini digunakan untuk memperoleh informasi terkait profil pondok yang meliputi jumlah guru, jumlah pengasuh, keadaan, sarana prasarana, serta data-data lain yang bersifat dokumen atau catatan dan foto-foto yang ada di pondok pesantren Misykatul Atsar guna melengkapi data peneliti.

Analisis data pada penelitian ini menggunakan reduksi, penyajian data, dan penyimpulan. Reduksi Data, dikarenakan data yang diperoleh di lapangan begitu banyak, perlu dilakukan analisis data dengan teknik reduksi. Mereduksi data berarti merangkum, memilih hal-hal yang pokok, memfokuskan pada hal-hal yang penting, dicari tema serta polanya dan membuang yang tidak perlu. Penyajian Data, yakni upaya menampilkan, memaparkan dan menyajikan secara jelas data-data yang dihasilkan dalam bentuk uraian singkat, bagan, hubungan antar kategori, gambar, tabel, dan sejenisnya.

Penyimpulan dan Verifikasi awal yang dikemukakan peneliti masih bersifat sementara, dan akan berubah jika ditemukan bukti-bukti kuat yang mendukung pada tahap pengumpulan data berikutnya. Sehingga pada tahap ini peneliti dapat melakukan konfirmasi dalam rangka mempertajam data dan memperjelas pemahaman serta tafsiran yang telah dibuat sebelum peneliti sampai pada kesimpulan akhir penelitian (Ibrahim,2015:108-110).

Pada penelitian ini pengecekan keabsahan data menggunakan teknik triangulasi. Adapun triangulasi yang digunakan peneliti adalah triangulasi sumber. Terkait teknik triangulasi sumber yang digunakan peneliti adalah menanyakan kembali kebenaran 
data dengan melalui informan yang lain. Hal ini dilakukan untuk mendapatkan kebenaran data terkait data proses pembelajaran matematika, urgensi pembelajaran matematika, dan cara menyiapkan kompetensi kognitif Santri pada pembelajaran matematika.

\section{HASIL DAN PEMBAHASAN}

Pada bab ini Peneliti menguraikan data dari hasil penelitian yang sudah dilakukan yakni tentang urgensi pembelajaran matematika Santri Pondok Pesantren Misykatul Atsar dan Cara menyiapkan kompetensi kognitif Santri Pondok Pesantren Misykatul Atsar.

\section{Urgensi Pembelajaran Matematika Pondok Pesantren Misykatul Atsar}

Berdasarkan dari hasil wawancara berikut adalah metode pembelajaran yang ada di pondok pesantren Misykatul Atsar :

Ceramah (Mulazamah). Metode ceramah adalah cara yang digunakan dalam mengembangkan proses pembelajaran melalui cara penuturan. Kebanyakan penyampaian materi di pondok pesantren Misykatul Atsar menggunakan metode ini baik dalam pelajaran agama maupun pelajaran umum.

Diskusi. Metode diskusi adalah cara menyajikan bahan pelajaran melalui proses pemeriksaan dengan teliti suatu masalah tertentu dengan jalan bertukar pikiran, bantahmembenah, dan memeriksa dengan teliti mengenai berbagai hal yang terdapat didalamnya dengan jalan menguraikan, membanding-badingkan, menilai hubungan itu, dan mengambil kesimpulan (Aqib, 2016: 63). Metode diskusi dilakukan oleh guru matematika untuk lebih bisa memahamkan Santri. Menurut salah satu guru matematika metode diskusi membuat siswa lebih aktif dan mudah paham.

Tanya Jawab. Metode pembelajaran tanya jawab adalah penyampaian pelajaran dengan cara pendidik memberi pertanyan dan peserta didik menjawab. Guru matematika melakukan metode ini untuk lebih bisa memahamkan Santri terkait materi yang sudah dipelajari. Dari metode pembelajaran yang digunakan, terdapat kendala dalam menerapkan metode tersebut, yaitu kurang aktifnya Santri dalam proses pembelajaran, minat belajar Santri dengan matematika yang rendah, dan keterbatasan waktu yang Santri terima dalam proses pembelajaran matematika, karena dalam satu bulan Santri hanya tatap muka sebanyak 4 kali atau bisa dikatakan seminggu sekali dengan waktu sekali tatap muka 1-2 jam. Waktu sesingkat itu santri dituntut untuk paham dengan materi yang cukup banyak untuk menyiapkan mereka melakukan kejar paket. Dari semua keterbatasan yang ada, ternyata pondok pesantren Misykatul Atsar menganggap pembelajaran matematika sebagai pelajaran yang penting.

Berdasarkan hasil penelitian, berikut alasanya: 1) Matematika sebagai bahasa untuk memahami ilmu pengetahuan. Meskipun di pondok pesantren ini lebih mengedepankan pelajaran agama, tapi tidak memupuk kemungkinan bahwa pelajaran matematika menjadi salah satu ilmu pengetahuan yang dibutuhkan. Contohnya dalam pelajaran fikih pada bab mawaris. Menghitung harta warisan sesuai dengan kedudukanya. 2) Matematika digunakan untuk memecahkan masalah. Banyak masalah yang bisa dipecahkan dengan matematika terlebih yang bersinggungan dengan kehidupan sehari-hari. Salah satunya dengan muamalah yang sering dipraktikan oleh

Tabel 1. Daftar Nilai Santri Tahun 2020 (Paket B)

NO NAMA NILAI

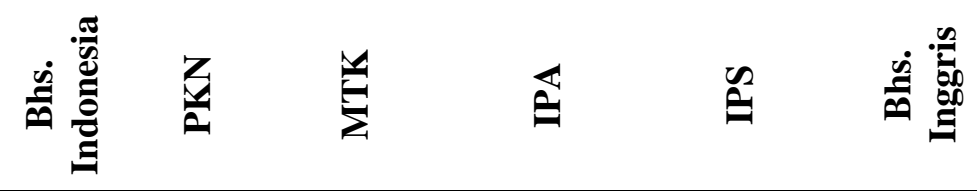

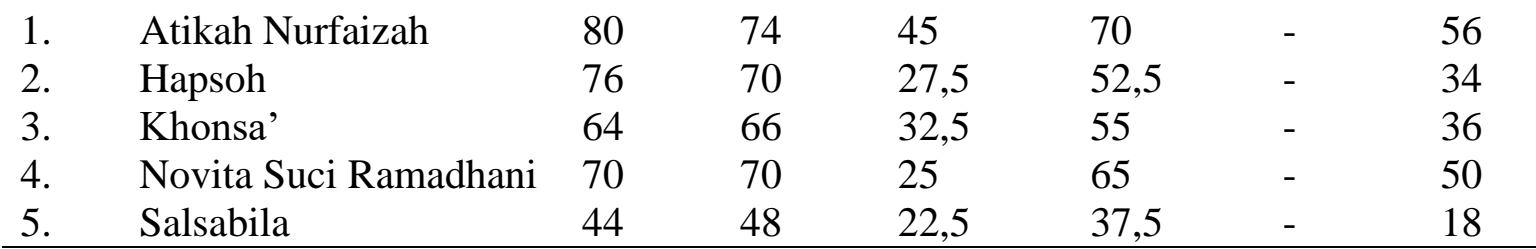


Tabel 2. Daftar Nilai Santri Tahun2020 (Paket C)

\begin{tabular}{|c|c|c|c|c|c|c|c|c|}
\hline \multirow[t]{2}{*}{ NO } & \multirow[t]{2}{*}{ NAMA } & \multicolumn{7}{|c|}{ NILAI } \\
\hline & & 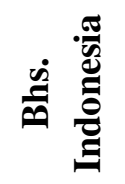 & Z & $\underline{\Sigma}$ & 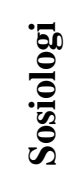 & 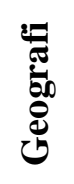 & $\begin{array}{l}\ddot{\Xi} \\
\overline{0} \\
\overline{0} \\
\frac{1}{x}\end{array}$ & 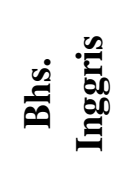 \\
\hline 1. & Atikah & 48 & 32 & 15 & 22 & 18 & 16 & 36 \\
\hline 2. & Dewi Syufaro' & 46 & 60 & 32,5 & 42 & 42 & 48 & 32 \\
\hline 3. & Fathimah & 64 & 52 & 17,5 & 48 & 28 & 38 & 32 \\
\hline
\end{tabular}

Santri, baik di lingkungan pondok ataupun di luar pondok. Setiap seminggu sekali santri diminta untuk belanja kebutuhan pokok ke pasar (sesuai jadwal). Saat berbelanja hal yang mereka harus tau adalah hitung-hitungan terkait praktik jual beli. Sehingga mereka merasa penting untuk mempelajari matematika.

3) Matematika sebagai implementasi ke pelajaran agama yang ada di pondok pesantren

Fokus pembelajaran pada pondok pesantren Misykatul Atsar memang pada pembelejaran agama, namun saat proses pembelajaran berlangsung tak memupuk kemungkinan matematika ikut serta dalam pembelajaranya. Contoh hal yang dipraktikan adalah tentang bab mawaris, muamalah, dan ilmu falak. 4) Matematika sebagai bekal ketika Santri sudah keluar dari pondok. Santri yang mencari ilmu di pondok ini tidak serta merta sepenuh hidupnya berada di pondok pesantren. Ada saatnya mereka meninggalkan pondok. Disaat seperti itu tentunya mereka akan bersinggungan dengan hiruk pikuk dunia masyarakat. Tidak baik ketika diantara mereka ada yang tidak bisa menghitung, sehingga cara yang harus dilakukan untuk mengantisipasi hal seperti itu adalah dengan mempelajari matematika.

Cara Menyiapkan Kompetensi Kognitif Santri Pondok Pesantren Misykatul Atsar

Pondok Pesantren Misykatul Atsar selalu mendaftarkan muridnya untuk sekolah kejar paket guna mendapatkan ijazah dan mendapatkan ilmu pengetahuan sebagai pelengkap ilmu agama yang diajarkan di pondok pesantren. Mekanisme kejar paket yang digunakan adalah setiap santri yang masuk pondok pesantren (bagi yang minat) langsung didaftarkan sekolah kejar paket sesuai jenjangnya. Dilihat dari hasil nilai kejar paket tahun 2020. Nilai matematika masih sangat jauh dibawah rata-rata. Berikut adalah perolehan nilai Santri kejar paket tahun 2020.

Terkait materi Ujian Nasional (UN) pondok pesantren Misykatul Atsar mengajarkanya dengan cara mendatangkan pendidik ke pondok setiap seminggu sekali. Dalam mensukseskan kejar paket dibutuhkan kompetensi kognitif yang harus dimiliki santri. Sehingga dibutuhkan cara dalam menyiapkan kompetensi kognitif santri untuk persiapan kejar paket

Guru sebagai fasilitator pembelajaran yang menyampaikan materi pembelajaran. Komponen penting dalam proses belajar mengajar. Guru adalah pembentuk akal dan karakter suatu bangsa. Cara guru matematika menyiapkan kompetensi kognitif santri pondok pesantren Misykatul Atsar adalah dengan memberi prolog dalam menyampaikan materi pembelajaran menggunakan bahasa yang mudah dipahami santri.

Kemudian cara lain yang dilakukan guru matematika untuk menyiapkan kompetensi kognitif santri yaitu menerangkan di depan kelas terkait materi yang sedang disampaikan dan memberi contoh soal kemudian diskusi tentang materi yang sudah disampaikan dengan tanya jawab, setelah jelas diberi soal latihan.

$$
\text { Pengurus bertugas sebagai }
$$
penyemangat, pengawas, dan pengontrol santri dalam kehidupan sehari-hari selama santri berada di lingkungan pondok pesantren. Baik mengenai aktivitas, rutinitas, psikologis, dan pengetahuan santri. Cara pengasuh menyiapkan 
kompetensi kognitif santri dalam pembelajaran matematika yaitu dengan mendatangkan guru matematika ke pondok untuk mengajar matematika setiap seminggu sekali dan sering memberinya latihan. Kemudian pengasuh dan pengurus meminta Santri untuk mengulang materi dengan teman, mengerjakan contohcontoh soal, membiasakan diri untuk menghitung, dan harus minat ketika belajar matematika.

Menilik bagaimana cara menyiapkan kompetensi kognitif santri, pastilah hal-hal yang menghambat dalam menyiapkan kompetensi kognitif santri pada pembelajaran matematika pastilah ada, berikut adalah hal-hal yang menghambat dalam menyiapkan kompetensi kognitif santri pondok pesantren Misykatul Atsar: 1) Tatap muka yang kurang. Tidak dipungkiri salah satu guru matematika merasa waktu yang diberikan untuk proses belajar mengajar matematika sangatlah kurang. Seminggu hanya sekali tatap muka dengan waktu 1-2 jam. Waktu pembelajaran banyak diberikan untuk pelajaran diniyah. Dalam hal ini cara mengatasinya dengan pendekatan melalui contoh, yakni memberi contoh dengan benda-benda yang ada disekeliling santri untuk dibuat alat peraga dari materi yang akan disampaikan. Berikut adalah jadwal pelajaran yang ada di pondok Pesantren Misykatul Atsar.

Tabel 3. Jadwal Pelajaran

\begin{tabular}{crlll}
\hline NO & WAKTU & \multicolumn{2}{l}{ MATA PELAJARAN } \\
\hline 1. & $08.00-09.00$ & Aqidah/matematika & \\
2. & $09.00-10.00$ & Fikih/IPA & \\
3. & $10.00-11.00$ & \multicolumn{2}{l}{ Bahasa Arab/IPS } & \\
4. & $11.00-12.00$ & $\begin{array}{l}\text { Tafsir } \\
\text { Tajwid/Bahasa }\end{array}$ \\
5. & $16.00-17.00$ & $\begin{array}{l}\text { Imla' (latihan menulis } \\
\text { arab) }\end{array}$ & \\
6. & $17.00-17.30$ & Nahwu & \\
\hline
\end{tabular}

Tabel 4. Kegiatan Para Santri

\begin{tabular}{lrlr}
\hline NO & WAKTU & \multicolumn{1}{c}{ KEGIATAN } \\
\hline 1. & $03.30-04.30$ & $\begin{array}{l}\text { Shalat Tahajjud dan } \\
\text { Tadarus }\end{array}$ \\
2. & $04.30-06.00$ & $\begin{array}{l}\text { Sholat Shubuh } \\
\text { berjamaah dan } \\
\text { Tahfidzul Qur'an } \\
\text { MCK }\end{array}$ \\
3. & $06.00-07.00$ & dan
\end{tabular}

\begin{tabular}{|c|c|c|}
\hline NO & WAKTU & KEGIATAN \\
\hline 4. & $07.00-08.00$ & Muroja'ah Al-Qur'an \\
\hline 5. & $08.00-12.00$ & $\begin{array}{l}\text { Pelajaran Diniyyah } \\
\text { (Agama) }\end{array}$ \\
\hline 6. & $12.00-13.00$ & $\begin{array}{l}\text { Shalat Dzuhur } \\
\text { berjamaah dan makan } \\
\text { siang }\end{array}$ \\
\hline 7. & $13.00-15.00$ & Tidur siang \\
\hline 8. & $15.00-16.00$ & $\begin{array}{l}\text { Sholat Ashar } \\
\text { beerjamaah dan mandi }\end{array}$ \\
\hline 9. & $16.00-17.30$ & Halaqoh Diniyyah \\
\hline 10. & $17.30-18.00$ & Istirahat \\
\hline 11. & $18.00-20.00$ & $\begin{array}{l}\text { Istirahat, Sholat } \\
\text { Maghrib dan Isya' } \\
\text { berjamaah, dan makan } \\
\text { malam }\end{array}$ \\
\hline 12. & $20.00-22.00$ & Halaqoh Tahfidz \\
\hline 13. & $22.00-03.30$ & Tidur \\
\hline
\end{tabular}

2) Mencari soal yang sesuai kemampuan peserta didik. Sudah menjadi permasalahan umum yang dirasakan oleh guruguru matematika lainya. Memang sudah kodratnya setiap peserta didik pasti mempunyai ciri khas pemikiran yang berbeda-beda. Apalagi di pondok pesantren Misykatul Atsar tergolong sekolah non formal. Cara guru matematika dalam mengatasinya yaitu dengan mengelompokan peserta didik sesuai tingkat kepahamanya yaitu mudah paham, susah paham, dan sedang kepahamanya kemudian diberi soal sesuai dengan kemampuanya.

3) Padatnya jadwal yang disusun oleh Pesantren. Banyaknya jadwal untuk pelajaran agama sehingga tidak banyak waktu untuk matematika. Apalagi di pondok ini mengharuskan santrinya untuk menghafal AlQur'an pastilah dibutuhkan waktu khusus untuk menghafal dan muroja'ah (mengulang hafalan). Dengan begitu cara yang digunakan untuk mengatasinya adalah dengan memberi semangat kepada para santri karena menimba ilmu itu tidak semudah membalik telapak tangan.

4) Kekurangan pengajar. Pondok pesantren ini tergolong pondok pesantren muda yang mana baru dirintis pada tahun 2008 . Sudah berjalan sekitar kurang lebih 12 tahun. Tak heran jika pengajar yang dibutuhkan tidak terpenuhi. Walhasil banyak orang yang kerjanya double alias merangkap. Berikut adalah daftar pengurus, pengasuh, dan pengajar di pondok pesantren Misykatul Atsar: 
Tabel 5. Struktur Kepengurusan

\begin{tabular}{lll} 
NO & \multicolumn{1}{c}{ JABATAN } & \multicolumn{1}{c}{ NAMA } \\
\hline 1. & $\begin{array}{l}\text { Kepala Ma'had } \\
\text { Putri }\end{array}$ & $\begin{array}{l}\text { Ustadzah Ummu } \\
\text { Ibrohim }\end{array}$ \\
2. & $\begin{array}{l}\text { Keungan dan } \\
\text { kesantrian }\end{array}$ & Hilmatunnisa \\
3. & $\begin{array}{l}\text { Ketertiban dan } \\
\text { konsumsi }\end{array}$ & Awalia Rizkiyati \\
4. & Koperasi & Robi'a Tsania \\
\hline
\end{tabular}

Tabel 6. Daftar Pengajar

\begin{tabular}{lll}
\hline NO & USTADZAH & \multicolumn{1}{c}{ PELAJARAN } \\
\hline 1. & Ummu Ibrohim & Aqidah dan Fikih \\
2. & AlKhonsa & Nahwu \\
3. & Ummu Ayyub & Bahasa Arab \\
4. & Fathimah & Tajwid dan Tahsin \\
5. & Hilmatunnisa & Tahfidz \\
6. & Robi'a Tsania & Tahfidz \\
7. & Nur Syamsiyah & Matematika \\
8. & Erma Liani & IPA, Matematika \\
& & dan Ekonomi \\
9. & Susi & Bahasa Inggris \\
\hline
\end{tabular}

Hal yang perlu dilakukan untuk mengatasinya adalah dengan mencari pengajar tentunya yang berkompeten dibidangnya.

5) Kurang minat dengan pelajaran matematika. Banyak santri yang mengatakan tidak minat dengan matematika, dengan berbagai alasanya. Seringnya mengatakan karena di pondok pesantren lebih fokus ke pelajaran agama dan bukan merupakan sekolah formal. Hal ini mempengaruhi nilai santri saat sekolah kejar paket berlangsung, pasalnya nilai matematika santri pada kejar paket tahun 2020 rata-rata berada dibawah angka 5 baik itu paket B ataupun paket C. Banyak cara untuk mengatasinya salah satunya dengan merasa bahwa matematika memang ilmu penting yang harus dipelajari dengan segudang manfaat salah satunya untuk pelengkap pelajaran agama.

Adapun hal-hal yang mendukung santri pondok pesantren Misykatul Atsar menyiapkan kompetensi kognitif dalam pembelajaran matematika adalah 1) Mendapat dukungan dari pondok pesantren; 2) Mempunyai pengajar yang siap mengajarkan ilmu matematika; 3) Ada dorongan untuk ikut ujian sekolah (kejar paket); 4) Pada pelajaran fikih muamalah mendorong untuk mempelajari matematika; 5) Saat proses pembelajaran berlangsung santri terkondisikan siap (tidak bercanda, tidak bicara sendiri, mendengarkan, dan memperhatikan); 6) Sumber materi dan contoh-contoh soal mudah didapat yakni bisa didapat dari internet dan buku; dan 7) Kemauan santri untuk mengulang materi matematika yang sudah disampaikan.

Dari hasil penelitian dan penjelasan diatas, bahwa matematika dianggap penting di pondok pesantren Misykatul Atsar. Kemudian terkait cara menyiapkan kompetensi kognitif Santri Pondok pesantren Misykatul Atsar dilakukan menurut cara guru dan juga cara pengasuh atau pengurus pondok posantren.

\section{SIMPULAN}

Berdasarkan hasil penelitian tentang urgensi pembelajaran matematika dalam menyiapkan kompetensi kognitif santri pondok pesantren (studi kasus pondok pesantren Misykatul Atsar di Salatiga tahun 2020) yang telah dilakukan, maka dapat ditarik kesimpulan bahwa urgensi pembelajaran matematika di pondok pesantren Misykatul Atsar adalah penting, dengan alasan yaitu Pertama, matematika sebagai bahasa untuk memahami ilmu pengetahuan. Contohnya dalam pelajaran fikih pada bab mawaris yang dipelajari Santri. Menghitung harta warisan sesuai dengan kedudukanya membutuhkan pelajaran matematika.

Kedua, matematika digunakan untuk memcahkan masalah. Contohnya dengan muamalah yang sering dipraktikan oleh santri, baik di lingkungan pondok ataupun di luar pondok. Ketiga, matematika sebagai ilmplementasi ke pelajaran agama yang ada di pondok pesantren. Contoh hal yang dipraktikan oleh pondok pesantren adalah tentang bab mawaris, muamalah, dan ilmu falak. Keempat, matematika sebagai bekal ketika Santri sudah keluar dari pondok. Pihak pondok pesantren tidak menginginkan ketika Santri sudah keluar dari pondok tetapi tidak bisa berhitung apalagi nantinya mereka akan bersinggungan dengan masyarakat.

Cara menyiapkan kompetensi kognitif dalam pembelajaran matematika pada santri pondok pesantren Misykatul Atsar yaitu pertama, Cara Guru menyiapkan kompetensi 
kognitif santri pondok pesantren Misykatul Atsar adalah dengan memberi prolog dalam menyampaikan materi pembelajaran menggunakan bahasa yang mudah dipahami santri. Kemudian dalam proses pembelajaran dengan cara menerangkan di depan kelas terkait materi yang sedang disampaikan dan memberi contoh soal kemudian diskusi tentang materi yang sudah disampaikan tadi dengan tanya jawab, setelah jelas diberi soal latihan.

Kedua, cara pengasuh menyiapkan kompetensi kognitif santri dalam pembelajaran matematika yaitu dengan mendatangkan guru matematika ke pondok untuk mengajar matematika setiap seminggu sekali dan sering memberinya latihan. Kemudian pengasuh dan pengurus meminta Santri untuk mengulang materi dengan teman, mengerjakan contohcontoh soal, membiasakan diri untuk menghitung, dan harus minat ketika belajar matematika.

\section{DAFTAR PUSTAKA}

Aqib Zainal,Ali Murtadlo. 2016. "Kumpulan metode pembelajaran kreatif dan inovatif". Bandung: Satu Nusa.

Ibrahim. 2015. "Metodologi Penelitian Kualitatif”. Bandung: Alfabeta.

Kemendikbud. 2013. "Kerangka Dasar dan Struktur Kurikulum 2013”. Jakarta: Kemendikbud.

Komalasari,Kokom. 2011. "Pembelajaran Kontekstual: Konsep dan Aplikasi". Bandung: Refika Aditama.
Kurniati, Annisah. 2015. "Mengenalkan Matematika Terintegrasi Islam Kepada Anak Sejak Dini”. Jurnal Of Mathemathics Education.1(1):4-5.

Martini,Jumaris. 2014. “Kesulitan Belajar Perspektif, Asesmen, dan Penanggulanganya". Bogor: Ghalia Indonesia.

Moleong,Lexy J. 2011. "Metodologi Penelitian Kualitatif". Bandung: PT. Remaja Rosdakarya.

Sumiati dan Asra. 2009. "Metode Pembelajaran". Bandung: CV Wacana Prima.

Wijaya, Ariyadi. 2012. "Pendidikan Matematika Realistik: Suatu Alternatid Pendekatan Pembelajaran Matematika". Yogyakarta: Graha Ilmu. 